${ }^{4}$ National Diabetes Data Group. Classification and diagnosis of diabetes mellitus and other categories of glucose intolerance. Diabetes 1979; 28:1039-57.

${ }^{5}$ Jarrett RJ, Keen H. Hyperglycaemia and diabetes mellitus. Lancet 1976; ii $: 1009-12$.

${ }^{6}$ Santiago JV, Davis JE, Fisher F. Hemoglobin Alc levels in a diabetes detection program. 7 Clin Endocrinol Metab 1978;47:578-80.

7 Dunn PJ, Cole RA, Soeldner JS, Gleeson RE. Reproducibility of hemoglobin Alc and sensitivity to various degrees of glucose intolerance. Ann Intern Med 1979;91:390-6.

${ }^{8}$ Bunn HF. Nonenzymatic glycosylation of protein: relevance to diabetes. Am 7 Med $1981 ; 70: 325-30$.

${ }^{9}$ Anonymous. Haemoglobin Al and diabetes: a reappraisal [Editorial]. Br Med f 1980;281:1304-5.

${ }^{10}$ Johnson RN, Metcalf PA, Baker JR. Fructosamine: a new approach to the estimation of serum glycosylprotein. An index of diabetic control. Clin Chim Acta 1983;127:87-95.

${ }^{11}$ Hodge JE. The Amadori rearrangement. Advances in Carbohydrate Chemistry 1955;10:169-205.

${ }^{12}$ Neese JW, Duncan P, Bayse D, Robinson M, Cooper T, Stewart C. Development and evaluation of a hexokinase/glucose-6-phosphate dehydrogenase procedure for use as a national glucose reference method. Washington: US Department of Health Education and Welfare, 1976. (Publication No (CDC) 77-8330.)
${ }^{13}$ Cole RA, Soeldner JS, Dunn PJ. A rapid method for the determination of glycosylated hemoglobins using high pressure liquid chromatography. Metabolism 1978;27:289-301.

14 Wilks SS. Mathematical statistics. Chichester: John Wiley, 1962.

${ }^{15}$ Skyler JS. Complications of diabetes mellitus: relationship to metabolic dysfunction. Diabetes Care 1979;2:499-509.

16 Pettitt DJ, Knowler WC, Lisse JR, Bennett PH. Development of retinopathy and proteinuria in relation to plasma-glucose concentrations in Pima Indians. Lancet $1980 ;$ ii :1050-2.

17 Varley H, Gowenlock AH, Bell M. Practical clinical biochemistry. Vol 1. London: William Heinemann, 1980.

18 Yue DK, Morris K, McLennan S, Turtle JR. Glycosylation of plasma protein and its relation to glycosylated hemoglobin in diabetes. Diabetes $1980 ; 29: 296-300$.

${ }^{19}$ Dolhofer R, Wieland OH. Increased glycosylation of serum albumin in diabetes mellitus. Diabetes $1980 ; 29: 417-22$.

20 Kennedy AL, Merimee TJ. Glycosylated serum protein and hemoglobin Al levels to measure control of glycemia. Ann Intern Med $1981 ; 95: 56-8$.

${ }^{21}$ Sandor G. Serum proteins in health and disease. London: Chapman and Hall, 1966.

22 Graf H, Stummvoll HK, Schernthaner G, Muller MM. Glycosylated haemoglobin in renal failure. Diabetologia 1980;19:555-6.

(Accepted 21 fune 1983)

\title{
Mortality from coronary heart disease and stroke in relation to degree of glycaemia: the Whitehall study
}

\author{
JOHN H FULLER, MARTIN J SHIPLEY，GEOFFREY ROSE， R JOHN JARRETT, HARRY KEEN
}

\begin{abstract}
In the Whitehall study of 18403 male civil servants aged 40-64 years the 10 year mortality rates from coronary heart disease and stroke showed a non-linear relation to two hour blood glucose values, with a significantly increased risk for glucose intolerant subjects with concentrations above the 95 th centile point $(5.4-11.0 \mathrm{mmol} / \mathbf{1}$; 96-199 $\mathrm{mg} / 100 \mathrm{ml}$ ) and for diabetics (blood glucose $\geqslant$ $11.1 \mathrm{mmol} / 1 ; \geqslant 200 \mathrm{mg} / 100 \mathrm{ml}$ ). Multiple logistic analysis showed that between one half and three quarters of the relative risks for deaths from coronary heart disease and stroke were "unexplained" by between group differences in risk factors such as age, blood pressure, obesity, smoking, cholesterol concentration, and electrocardiographic abnormalities. Within the glucose intolerant and diabetic groups the risk factors most strongly related to subsequent death from coronary heart disease were age and blood pressure, with less consistent relations for smoking, cholesterol concentration, and obesity.

This study confirms the importance of hypertension as a cardiovascular risk factor in groups with glucose intolerance and diabetes, and this may have important preventive implications.
\end{abstract}

\footnotetext{
Department of Community Medicine, Middlesex Hospital Medica School, Central Middlesex Hospital, London NW10 7NS JOHN H FULLER, MRCP, senior lecturer

London School of Hygiene and Tropical Medicine, London MARTIN J SHIPLEY, MSC, medical statistician GEOFFREY ROSE, FRCP, professor of epidemiology

Guy's Hospital, London

R JOHN JARRETT, MD, reader in community medicine HARRY KEEN, FRCP, professor of human metabolism

Correspondence to: Dr John H Fuller.
}

\section{Introduction}

Mortality statistics for England and Wales ${ }^{1}$ and other countries $^{23}$ support the findings of several large cohort studies ${ }^{3-6}$ in showing increased mortality from coronary heart disease and stroke associated with diabetes mellitus. The Whitehall study ${ }^{7}$ and several other studies ${ }^{8-10}$ have also shown an increased mortality from coronary heart disease in subjects with raised blood glucose concentrations indicative of glucose intolerance but below those diagnostic of diabetes mellitus. ${ }^{11}$ Nevertheless, the relation of asymptomatic hyperglycaemia to other forms of occlusive vascular disease such as stroke remains unclear. Only limited data are available from prospective studies of the relative importance of established risk factors for coronary heart disease-hypertension, hypercholesterolaemia, cigarette smoking-in the aetiology of the vascular disease associated with glucose intolerance and diabetes. ${ }^{1213}$ We have therefore examined the relation of various degrees of glycaemia and other possible risk factors to mortality from coronary heart disease and stroke using 10 year mortality data from the Whitehall study.

\section{Subjects and methods}

In the Whitehall study 18403 male civil servants aged 40 to 64 were examined between 1967 and 1969 and their records tagged at the Central Registry of the National Health Service. A virtually complete 10 year mortality follow up was therefore available for the group.

At the screening examination a resting electrocardiogram (limb leads only) was recorded and classified according to the Minnesota code. ${ }^{14}$ Abnormal tracings were defined as those with the following Minnesota code items (Whitehall criteria): Q/QS waves $(1 \cdot 1-1 \cdot 3)$; $S-T$ depressions $(4 \cdot 1-4 \cdot 4) ; T$ wave inversion or flattening $(5 \cdot 1-5 \cdot 3)$ or left bundle branch block $(7 \cdot 1)$. Arterial blood pressure was measured using the London School of Hygiene sphygmomanometer with the subjects sitting. Body mass index was calculated as weight $(\mathrm{kg}) / \mathrm{height}$ $(\mathrm{m})^{2}$.

Subjects attended on the morning after an overnight fast and capil- 
lary blood samples were taken two hours after a $50 \mathrm{~g}$ oral glucose load. Blood glucose and cholesterol concentrations were measured as described.15 "Known diabetics" and "hypertensives on treatment" were identified from questionnaire responses. For this analysis subjects were divided into three groups.

Diabetic group-This group comprised 224 subjects, of whom 168 were "known diabetics" and 56 had a blood glucose concentration of $\geqslant 11 \cdot 1 \mathrm{mmol} / 1(\geqslant 200 \mathrm{mg} / 100 \mathrm{ml})$. Of the known diabetics, 46 were receiving insulin.

Glucose intolerant group-This group comprised 999 subjects with blood glucose concentrations above the 95 th centile point $(5 \cdot 4-11 \cdot 0$ $\mathrm{mmol} / \mathrm{l}$; 96-199 mg/100 ml).

Normoglycaemic group-This group comprised 17051 subjects whose blood glucose concentrations were below $5.4 \mathrm{mmol} / 1$.

Adjustment for age was carried out by direct standardisation, using the total population as the standard, and tests for trend were made using the Mantel extension of the Mantel-Haenszel procedure. ${ }^{16}$ Multivariate analysis was carried out using the multiple logistic equation, ${ }^{17}$ which also yielded estimates of the extent to which differences in risk between groups classified by degree of glycaemia were attributable to the independent effect of certain risk factors.

\section{Results}

Mortality from all causes-Age adjusted rates of mortality from all causes did not differ significantly between men found to be diabetic at the survey (blood glucose $\geqslant 11 \cdot 1 \mathrm{mmol} / \mathrm{l}$ ) and previously known diabetics. Within the latter group mortality rates did not differ significantly between those treated with and without insulin and were not related to duration of diabetes. All diabetics were therefore combined in the present analysis.

Mortality from stroke and coronary heart disease and degree of glycaemia-Figure 1 shows the age adjusted 10 year mortality rates for stroke (ICD codes 430-438) and coronary heart disease (ICD codes 410-414) by blood glucose concentrations up to $11 \cdot 1 \mathrm{mmol} / 1$ and for diabetics. Altogether there were 92 deaths from stroke, of which 17 were assigned to "subarachnoid haemorrhage" (ICD 430), 22 to "cerebral haemorrhage" (ICD 431), 38 to "acute but ill-defined cerebrovascular disease" (ICD 436), and the remainder to other categories. No trend in mortality from stroke for blood glucose concentrations below the 90 th centile $(<5.0 \mathrm{mmol} / \mathrm{l} ;<89 \mathrm{mg} / 100 \mathrm{ml})$ was apparent, but mortality was increased, but not significantly so, for those in the $90-95$ th centile range $(5 \cdot 0-5 \cdot 3 \mathrm{mmol} / 1 ; 89-95 \mathrm{mg} / 100$ $\mathrm{ml})$ and doubled $(\mathrm{p}<0.05)$ above the 95 th centile $(5 \cdot 4-11.0 \mathrm{mmol} / \mathrm{l})$. Mortality rates from stroke were also increased in diabetics, but the number of deaths was small. A total of 721 deaths from coronary heart disease had occurred at 10 years, and mortality from this cause showed a sharp increase above the 95th centile of blood glucose values $(p<0.001)$. The mortality rate from coronary heart disease in diabetics was also significantly greater than that in normoglycaemic subjects (blood glucose $<5.4 \mathrm{mmol} / \mathrm{l})(\mathrm{p}<0.01)$.

Mortality from stroke and other risk factors-Figure 2 shows the relations of age adjusted stroke mortality rates to quintiles of systolic and diastolic blood pressure, the rates for treated hypertensives being plotted separately. Men in the highest systolic quintile had 12 times and treated hypertensives 25 times the mortality from stroke compared with those in the lowest two quintiles. Also mortality from stroke was increased about two and a half times in men smoking 10 or more cigarettes a day compared with non-smokers $(p<0 \cdot 01)$. The relation of stroke mortality to obesity was non-linear, with a doubling of mortality for men in the upper quintile of body mass index compared with the lower four quintiles.

Multiple logistic anaiysis-Several of the possible risk factors for mortality from both coronary heart disease and stroke are correlated with each other and with blood glucose. ${ }^{18}$ The independent contribution of several variables to mortality was therefore assessed by a multiple logistic analysis ${ }^{17}$ (table I); diabetics were excluded. Blood glucose was entered into the analysis as two dichotomous variables: $5 \cdot 0-5 \cdot 3 \mathrm{mmol} / 1$ (yes/no) and 5.4-11.0 mmol $/ 1$ (yes/no), corresponding to the 90-95th centile range and the range above the 95th centile respectively. In table I the variable "ex-smoker" compares ex-cigarette smokers and non-smokers, "smoker" compares cigarette smokers and non-smokers, and "cigarettes/day" gives the quantity effect within cigarette smokers. Administrative, professional, and executive grades are classified as "upper" work grade and clerical and other grades as "lower" work grade. Variables significantly predictive of mortality from both stroke and coronary heart disease were age, systolic blood pressure, treatment for blood pressure, and a blood glucose value $\geqslant 5.4 \mathrm{mmol} / \mathrm{l}$. Additional variables significantly related to mortality from coronary heart disease were cigarette smoking, number of cigarettes a day, lower work grade, cholesterol value, and an abnormal electrocardiogram.

Risk factors for coronary heart disease and degree of glycaemiaFigure 3 shows the relations of age adjusted mortality from coronary heart disease to quintiles of systolic and diastolic blood pressure in each of the three study groups. There were significant upward trends in mortality with systolic and diastolic pressure for both the glucose

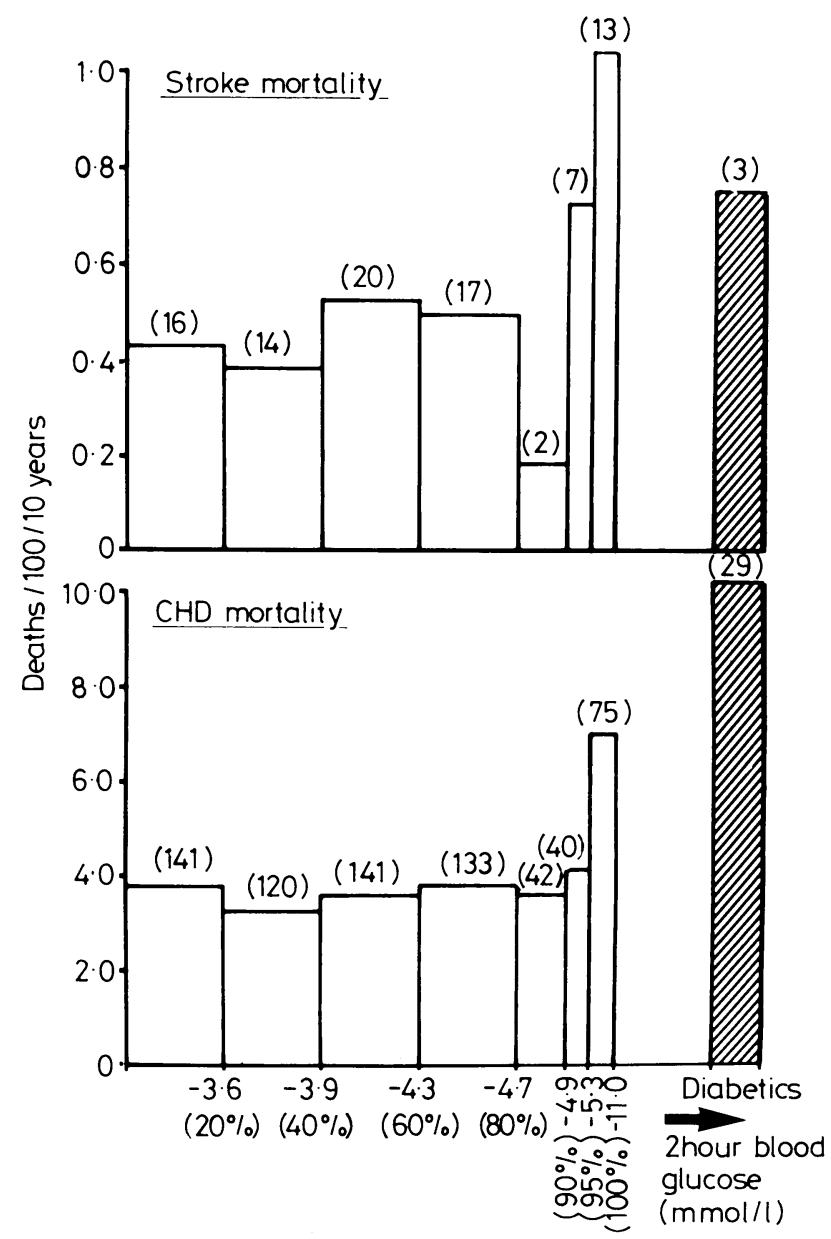

FIG 1-Age adjusted 10 year stroke and coronary heart disease (CHD) mortality by two hour blood glucose concentration. Numbers at top of columns are numbers of deaths. Percentages are centile points.

Conversion: SI to traditional units-Glucose: $1 \mathrm{mmol} / 1 \approx 18 \mathrm{mg} /$ $100 \mathrm{ml}$.

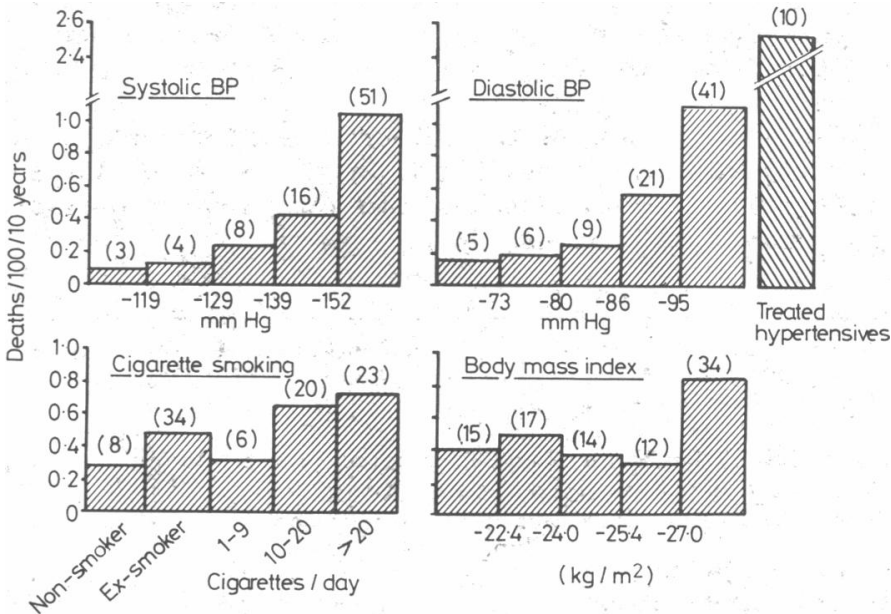

FIG 2-Age adjusted 10 year stroke mortality by systolic blood pressure (BP), diastolic BP, smoking habits, and body mass index. Numbers at top of columns are numbers of deaths. 
TABLE I-Multiple logistic analysis of relation between several variables and 10 year stroke and coronary heart disease (CHD) mortality. (Excludes diabetics, and includes only subjects with complete information)

\begin{tabular}{|c|c|c|c|c|}
\hline \multirow[b]{3}{*}{ Independent variables } & \multicolumn{4}{|c|}{ Mortality } \\
\hline & \multicolumn{2}{|c|}{ Stroke } & \multicolumn{2}{|c|}{$\mathrm{CHD}$} \\
\hline & $\beta$ & $t$ value & $\beta$ & $t$ value \\
\hline $\begin{array}{l}\text { Age (years) } \\
\text { Ex-smoker (yes/no) } \\
\text { Smoker (yes/no) } \\
\text { Cigarettes/day } \\
\text { Lower work grade (yes/no) } \\
\text { Systolic blood pressure }(\mathrm{mm} \mathrm{Hg}) \\
\text { Cholesterol (mmol/1) } \\
\text { Bedy mass index }\left(\mathrm{kg} / \mathrm{m}^{2}\right) \\
\text { Whitehall electrocardiographic abnormality }\end{array}$ & $\begin{array}{r}0.11 \\
0.42 \\
0.33 \\
0.03 \\
0.06 \\
0.03 \\
-0.02 \\
-0.01\end{array}$ & $\begin{array}{l}4 \cdot 8^{* * * *} \\
1 \cdot 1 \\
0 \cdot 7 \\
1 \cdot 9 \\
0 \cdot 2 \\
8 \cdot 2 * * * \\
-0 \cdot 2 \\
-0 \cdot 4\end{array}$ & $\begin{array}{l}0.07 \\
0.10 \\
0.60 \\
0.01 \\
0.29 \\
0.01 \\
0.24 \\
0.02\end{array}$ & $\begin{array}{l}9 \cdot 9^{* * *} \\
0 \cdot 7 \\
3 \cdot 8^{* * *} \\
2 \cdot 1^{*} \\
3 \cdot 2^{* *} \\
7 \cdot 3^{* * *} \\
7 \cdot 5^{* * *} \\
1 \cdot 4^{*}\end{array}$ \\
\hline $\begin{array}{l}\text { (yes/no) } \\
\text { Treatment for blood pressure (yes/no) } \\
\text { Blood glucose } 90-95^{\circ}{ }^{\circ} \text { (yes/no) } \\
\text { Blood glucose } 95^{\circ}{ }^{\circ} \text { (yes/no) } \\
\text { Intercept }\end{array}$ & $\begin{array}{r}0.35 \\
0.63 \\
0.44 \\
0.66 \\
-16.44\end{array}$ & $\begin{array}{l}1 \cdot 2 \\
2 \cdot 8^{* *} \\
1 \cdot 1 \\
2 \cdot 0^{*}\end{array}$ & $\begin{array}{r}1.06 \\
0.47 \\
0.16 \\
0.48 \\
-11.58\end{array}$ & $\begin{array}{l}9 \cdot 7^{* * *} \\
5 \cdot 4^{* * *} \\
0 \cdot 9 \\
3 \cdot 4^{* * *}\end{array}$ \\
\hline $\begin{array}{l}\text { No of cases } \\
\text { No of subjects }\end{array}$ & & & & \\
\hline
\end{tabular}

${ }^{*} \mathrm{p}<0.05 ; \quad * * \mathrm{p}<0.01 ; \quad * * * \mathrm{p}<0.001$

Conversion: SI to traditional units-Cholesterol: $1 \mathrm{mmol} / 1 \approx 38.6 \mathrm{mg} / 100 \mathrm{ml}$.
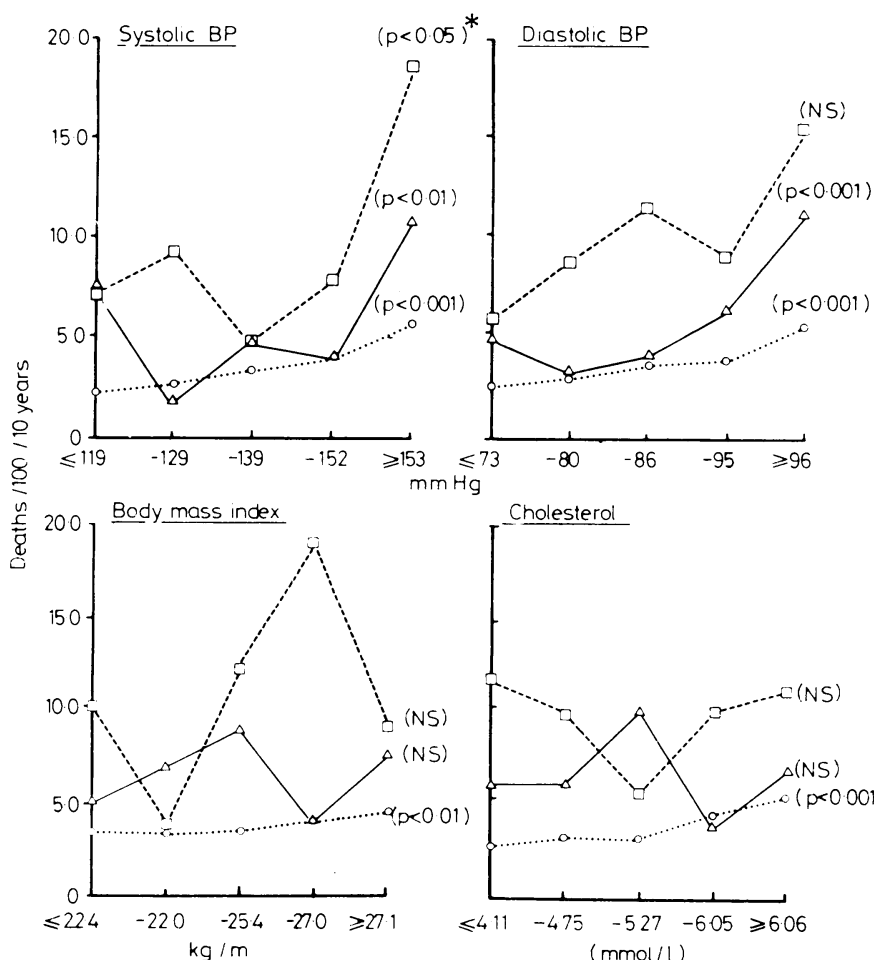

FIG 3-Age adjusted 10 year coronary heart disease mortality by systolic blood pressure (BP), diastolic BP, body mass index, and cholesterol concentration for normoglycaemic group $(\mathrm{O} \cdots \cdots \mathrm{O})$, glucose intolerant group $(\triangle-\triangle)$, and diabetic group $(\square---\square)$.

*Significance level of $\chi^{2}$ test for trend. (NS $=$ Not significant.) $\mathrm{ml})$.

Conversion: SI to traditional units-Cholesterol: $1 \mathrm{mmol} / \mathrm{l} \approx 38.6 \mathrm{mg} / 100$

intolerant and normoglycaemic groups. In the diabetics the upward trend was significant for only systolic pressure, but diabetics in the upper quintile of diastolic pressure had mortality rates twice those in the lower two quintiles. These relations of mortality from coronary heart disease to blood pressure were not significantly altered when subjects receiving treatment for hypertension were excluded from the analysis. In the univariate analysis body mass index and blood cholesterol concentration (fig 3) showed a significant positive association with death from coronary heart disease only in the normoglycaemic group. Mortality from coronary heart disease had a significant relation with cigarette smoking in the normoglycaemic group, but the findings were inconsistent for the glucose intolerant and diabetic groups (table II). Men in the lower work grades had higher mortality from coronary heart disease in the normoglycaemic and diabetic groups (significantly so in the former) but not in the glucose intolerant group. There was an excess mortality for subjects with abnormal electrocardiograms, the relative risks being $3 \cdot 4,2 \cdot 8$, and 1.8 for the normoglycaemic, glucose intolerant, and diabetic groups respectively.

Relative risks of death from stroke and coronary heart disease and degree of glycaemia-Figure 4 shows the relative risks (odds ratios) of death from stroke and coronary heart disease in the glucose intolerant and diabetic groups compared with those in the normoglycaemic group. The multiple logistic equation may be used to estimate how much of the difference in relative risk between the groups was attributable to differences in risk factors. For the glucose intolerant and diabetic groups the proportions of relative risk "unexplained" by measured risk factors were $63 \%$ and $52 \%$ respectively for death from stroke, and $75 \%$ and $63 \%$ respectively for death from coronary heart disease. Apart from age, the variable making the largest single contribution to the risk of death from stroke or coronary heart disease was systolic blood pressure.

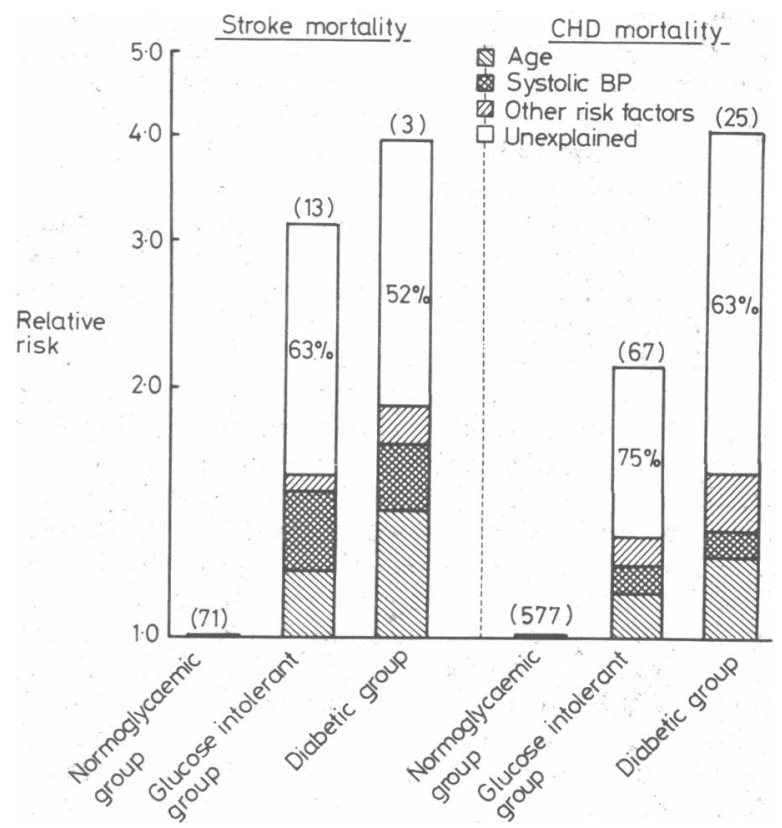

FIG 4-Relative risks (odds ratios) of stroke death and coronary heart disease (CHD) death explained by risk factors (age standardised) for (a) glucose intolerant group and (b) diabetic group compared with normoglycaemic group. Figures at top of columns are numbers of deaths. Includes only subjects with complete information.

TABLE II-Ten year age adjusted coronary heart disease mortality* by smoking, work grade, electrocardiographic abnormalities, and degree of glucose intolerance. work grade, electrocardiographic abnormalities,
(Figures in parentheses are numbers of deaths)

\begin{tabular}{|c|c|c|c|}
\hline & $\begin{array}{l}\text { Normoglycaemic } \\
\text { group }\end{array}$ & $\begin{array}{l}\text { Glucose intolerant } \\
\text { group }\end{array}$ & $\begin{array}{l}\text { Diabetic } \\
\text { group }\end{array}$ \\
\hline $\begin{array}{l}\text { Non-smoker } \\
\text { Ex-smoker } \\
\text { Current smoker }\end{array}$ & $\begin{array}{l}2 \cdot 03(55) \\
2 \cdot 73(171) \\
5 \cdot 11(371)\end{array}$ & $\begin{array}{l}7 \cdot 44(14) \\
5 \cdot 08(23) \\
7 \cdot 71(37)\end{array}$ & $\begin{array}{r}3.08(2) \\
11.78(14) \\
8.93(10)\end{array}$ \\
\hline$x^{2}(2 \mathrm{df})$ & $69 \cdot 9 * * *$ & 3.0 & $4 \cdot 8$ \\
\hline $\begin{array}{l}\text { Upper work grade } \\
\text { Lower work grade }\end{array}$ & $\begin{array}{l}3.17(356) \\
4.89(239)\end{array}$ & $\begin{array}{l}6 \cdot 44(44) \\
6 \cdot 73(30)\end{array}$ & $\begin{array}{r}8 \cdot 87(12) \\
12.96(17)\end{array}$ \\
\hline$x^{2}(1 \mathrm{df})$ & $25 \cdot 1^{* * *}$ & 0.03 & $1 \cdot 1$ \\
\hline $\begin{array}{l}\text { Normal electrocardiogram } \\
\text { Abnormal electrocardiogram }\end{array}$ & $\begin{array}{r}3 \cdot 11(483) \\
10 \cdot 70(132)\end{array}$ & $\begin{array}{r}5 \cdot 24(53) \\
14 \cdot 81(19)\end{array}$ & $\begin{array}{r}8 \cdot 74(21) \\
15.91(6)\end{array}$ \\
\hline$x^{2}(1 \mathrm{df})$ & $129 \cdot 9 * * *$ & $13 \cdot 8^{* * *}$ & 1.58 \\
\hline
\end{tabular}

*Age adjusted mortality rates $/ 100 \mathrm{men} / 10$ years.
$* * * \mathrm{p}<0.001$.

\section{Discussion}

Several studies have detected an increased prevalence of diabetes among cases of stroke ${ }^{12}$ but diagnostic criteria for diabetes were variable and the choice of cases and control groups often lacked representativeness. In the Framingham study there 
was a twofold increase in the incidence of stroke in diabetics of both sexes, ${ }^{6}$ and in a cohort of 6000 members of the British Diabetic Association the standardised mortality ratios for cerebrovascular disease were significantly increased at 142 for both men and women. ${ }^{1}$ Several studies ${ }^{19-21}$ have shown that the incidence of stroke is strongly related to blood pressure and, to a less extent, obesity-both of which are correlated with the blood glucose concentration. ${ }^{13}{ }^{18}$ The increased risk of death from stroke associated with blood glucose values above the 95th centile, however, remains significant when adjustment is made for other risk factors for stroke using multiple logistic analysis (table I). Thus mortality from stroke in the Whitehall study shares with that from coronary heart disease an independent, non-linear relation to blood glucose.

This analysis of 10 year mortality data confirms the sharp doubling of risk of coronary heart disease above the 95 th centile of the blood glucose distribution found in the previous seven and a half year mortality analysis, ${ }^{7}$ and this increased risk persisted after adjustment for other associated variables (table I). This non-linear pattern of cardiovascular risk associated with hyperglycaemia has been confirmed by some prospective studies $^{8-10}$ but not by others. ${ }^{22}$ The possible reasons for these divergent findings have been discussed elsewhere ${ }^{723}$ but may be related to the large sample size required to detect a significantly increased risk at the extreme of the blood glucose distribution. A 10 year mortality analysis of "borderline diabetics" from the Bedford survey confirmed that their mortality rates from all causes and from coronary heart disease were higher than in matched controls, but when adjustment was made for other risk factors the differences were significant only for all deaths in women. ${ }^{24}$

Little information is available for groups with glucose intolerance or diabetes on the predictive power of risk factors for coronary heart disease established for normoglycaemic populations. The abnormalities of serum lipids and lipoproteins associated with the main types of diabetes have been extensively studied $^{25}$ but their role in the pathogenesis of diabetic large vessel disease remains uncertain, ${ }^{26}$ and the present study of middle aged men shows no significant relation of cholesterol to risk of coronary heart disease in the glucose intolerant and diabetic groups. Both the Whitehall and Bedford studies showed no linear relation of obesity to risk of coronary heart disease in subjects with glucose intolerance, and for Whitehall participants as a whole the relation of obesity to total mortality was non-linear and depended on age. ${ }^{27}$ In contrast to the Whitehall study, the glucose intolerant subjects in the Bedford study showed a significant relation of cigarette smoking to mortality from coronary heart disease. ${ }^{24}$

An analysis of the Framingham study, in which 239 of the original cohort of 5209 men and women were defined as having diabetes, suggested that the relation of risk factors to the incidence of cardiovascular disease over a 20 year period does not differ between diabetics and non-diabetics. ${ }^{28}$ This is not confirmed by the present study of male civil servants, since systolic and diastolic blood pressure had a more consistent relation to mortality from coronary heart disease in the glucose intolerant and diabetic groups than cholesterol concentration, body mass index, cigarette smoking, and work grade. Hypertension may also be of possible importance in the actiology of diabetic renal disease ${ }^{29}$ and exudative retinopathy, ${ }^{30}$ and its early treatment in diabetic and glucose intolerant groups may therefore have important preventive implications. The multiple logistic analysis shows, however, that only a small proportion of the increased risk of deaths from stroke and coronary heart disease associated with hyperglycaemia can be explained in terms of cardiovascular risk factors established for the nondiabetic population.

We thank the Civil Service for their collaboration, Miss Linda Colwell for help with data processing, and the Department of Health and Social Security and the Tobacco Research Council for financial support.

\section{References}

${ }^{1}$ Fuller JH, Elford J, Goldblatt P, Adelstein AM. Diabetes mortality: new light on an underestimated public health problem. Diabetologia 1983; 24:336-41.

Sasaki A, Kamado K, Horiachi N. A changing pattern of causes of death in Japanese diabetics. Observations over fifteen years. $\mathcal{f}$ Chronic Dis $1978 ; 31: 433-44$

${ }^{3}$ Marks HH, Krall LP. Onset, course, prognosis and mortality in diabetes mellitus. In: Marble A, White P, Bradley RF, Krall LP, eds. Foslin's diabetes mellitus. 11th ed. Philadelphia: Lea and Febiger, 1971:209.

4 Hayward RE, Lucena BC. An investigation into the mortality of diabetics. Fournal of the Institute of Actuaries 1965;91:286-336.

5 Shenfield GM, Elton RA, Bhalla IP, Duncan LJP. Diabetic mortality in Edinburgh. Diabete Metab 1979;5:149-58.

${ }^{6}$ Garcia MJ, McNamara PM, Gordon T, Kannell WB. Morbidity and mortality in diabetics in the Framingham population. Sixteen year follow-up study. Diabetes $1974 ; 23: 105-11$.

${ }^{7}$ Fuller JH, Shipley MJ, Rose G, Jarrett RJ, Keen H. Coronary-heart disease and impaired glucose tolerance: the Whitehall study. Lancet $1980 ; \mathrm{i}: 1373-6$.

${ }^{8}$ Pyorala K, Savolainen E, Lehtovirta E, Punsar S, Siltanen P. Glucose tolerance and coronary heart disease. Helsinki policemen study. $\mathcal{F}$ Chronic Dis 1979;32:729-45.

${ }^{9}$ Ducimetiere P, Eschwege E, Richard J, Rosselin G, Claude JR. Clinical complications of coronary heart disease according to plasma insulin and glucose levels. A further analysis of the Paris prospective study. In: Eschwege $\mathrm{E}$, ed. Advances in diabetes epidemiology. Amsterdam: Elsevier Biomedical Press, 1982:149. (INSERM symposium No 22.)

10 Yano K, Kagan A, McGee D, Rhoads GG. Glucose intolerance and nineyear mortality in Japanese men in Hawaii. $A m \mathcal{F}$ Med $1982 ; 72: 71-80$.

11 WHO Expert Committee on Diabetes Mellitus. Second report. WHO Tech Rep Ser 1980; No 646.

12 West KM. Epidemiology of diabetes and its vascular lesions. New York: Elsevier, 1978:351.

13 Jarrett RJ, Keen H, Chakrabarti R. Diabetes, hyperglycaemia and arterial disease. In: Keen H, Jarrett J, eds. Complications of diabetes. 2nd ed. London: Edward Arnold, 1982:179.

14 Rose G, Blackburn H. Cardiovascular survey methods. WHO Monogr Ser 1968; No 56.

15 Reid DD, Brett GZ, Hamilton PJS, Jarrett RJ, Keen H, Rose G. Cardiorespiratory disease and diabetes among middle-aged male civil servants: a study of screening and intervention. Lancet $1974 ; \mathrm{i}: 469-73$.

${ }_{16}$ Mantel N. Chi-square tests with one degree of freedom; extensions of the Mantel-Haenszel procedure. Fournal of the American Statistical Association 1963;58:690-700.

17 Walker SH, Duncan DB. Estimation of the probability of an event as a function of several independent variables. Biometrika 1967;54:167-79.

18 Stamler R, Stamler J. Asymptomatic hyperglycemia and coronary heart disease. A series of papers by the International Collaborative Group based on studies in fifteen populations. Introduction. $\mathcal{f}$ Chronic Dis $1979 ; 32: 683-91$.

19 Paffenbarger RS, Wing AL. Characteristics in youth predisposing to fatal stroke in later years. Lancet $1967 ; \mathrm{i}: 753-4$.

${ }^{20}$ Kannel WB, Wolf PA, Verter J, McNamara PM. Epidemiologic assessment of the role of blood pressure in stroke. The Framingham study. 7 $A M A$ 1970;214:301-10.

${ }^{21}$ Rhoads GG, Kagan A. The relation of coronary heart disease, stroke and mortality to weight in youth and in middle age. Lancet 1983; : 492-5.

22 International Collaborative Group. Joint discussion. 7 Chronic Dis 1979; 32:829-37.

${ }^{23}$ Fuller JH, McCarthy P, Jarrett RJ, et al. Hyperglycemia and coronary heart disease: the Whitehall study. 7 Chronic Dis $1979 ; 32: 721-8$.

${ }^{24}$ Jarrett RJ, McCarthy P, Keen $H$. The Bedford survey: ten year mortality rates in newly diagnosed diabetics, borderline diabetics and normoglycaemic controls and risk indices for coronary heart disease in borderline diabetics. Diabetologia $1982 ; 22: 79-84$

${ }^{25}$ Steiner G. Diabetes and atherosclerosis-an overview. Diabetes $1981 ; 30$, suppl $2: 1-7$.

${ }^{26}$ Fuller JH, Salter A, Mattock M. Lipids and diabetic macro-angiopathy: the role of high-density lipoprotein. In: Eschwege E, ed. Advances in diabetes epidemiology. Amsterdam: Elsevier Biomedical Press, 1982:157. (INSERM symposium No 22.)

27 Jarrett RJ, Shipley MJ, Rose G. Weight and mortality in the Whitehall study. Br Med f 1982;285:535-7.

${ }^{28}$ Kannel WB, McGee DL. Diabetes and cardiovascular risk factors: the Framingham study. Circulation 1979;59:8-13.

29 Christlieb AR, Warram JH, Krolewski AS, et al. Hypertension: the major risk factor in juvenile-onset insulin-dependent diabetics. Diabetes 1981; 30, suppl $2: 90-6$.

${ }^{30}$ Knowler WC, Bennett PH, Ballintine EJ. Increased incidence of retinopathy in diabetics with elevated blood pressure. $N$ Engl f Med 1980; 302:645-50. 